\title{
Potential Energy Efficiency and Solar Energy Applications in a Small Industrial Laundry: A Practical Study of Energy Audit
}

\author{
Erkata Yandri $^{1,2^{*}}$, Ratna Ariati ${ }^{1,2}$, Aep Saepul Uyun ${ }^{1,2}$, Roy Hendroko Setyobudi ${ }^{1,3}$, \\ Herry Susanto ${ }^{1}$, Kamaruddin Abdullah ${ }^{1,2}$, Satriyo Krido Wahono ${ }^{4}$, \\ Yogo Adhi Nugroho ${ }^{5,6}$, Abubakar Yaro ${ }^{7}$, and Juris Burlakovs ${ }^{8}$ \\ ${ }^{1}$ Graduate School of Renewable Energy, Darma Persada University, Jl. Radin Inten 2, \\ Pondok Kelapa, East Jakarta 13450, Indonesia \\ ${ }^{2}$ Center of Renewable Energy Studies, Darma Persada University, \\ ${ }^{3}$ Department of Agriculture Science, Postgraduate Program, University of Muhammadiyah Malang, \\ Jl. Raya Tlogomas No. 246, Malang, 65145, East Java, Indonesia \\ ${ }^{4}$ Research Division for Natural Product Technology - Indonesian Institute of Sciences, \\ Jl. Jogja - Wonosari, km 31.5, Gunung Kidul, Special Region Yogyakarta 55861, Indonesia \\ ${ }^{5}$ Individual Researcher, Alumni Graduate School of IPB University, Bogor, Indonesia \\ ${ }^{6}$ Data Processing, Rumah Paper Kita-Editage Services, Jl. Tokala No.1, Malang 65146, \\ East Java, Indonesia \\ ${ }^{7}$ Institute of Health Sciences \& Research, AHRO Scientific Publishing, 272 Bath Street, \\ Glasgow G2 4JR, Scotland, UK \\ ${ }^{8}$ Department of Water Management, Estonian University of Life Sciences, Tartu, Estonia; \\ Friedrich Reinhold Kreutzwaldi 1a, 51014 Tartu, Estonia
}

\begin{abstract}
The purpose of this study is to analyze the potential for energy savings because the laundry industry consumes a lot of energy and water. If the laundry industries are not controlled, it will cause serious environmental and energy problems. The audit activity was divided into three stages. Pre-audit stage, the auditors were divided into groups with clear details of tasks and responsibilities, starting with conducting energy audits on the floor, analyzing statistical data, and process flow. Site audit stage; conduct an audit on the floor from the beginning to the end of the process, then collecting and confirming the statistical data for energy and production. Post-audit stage, complete the audit report that will be submitted or presented to the laundry management, which consists of; audit findings with loss or savings analysis, accompanied by recommendations for further improvement. The results show that there are many savings opportunities, especially by overcoming the energy wasted in the production process. Improvements can be made by overcoming energy waste and controlling energy consumption and production more efficiently, implementing renewable energy technology such as solar dryer and hybrid photovoltaic and thermal (PVT) collector, and then considering industrial revolution 4.0 with IoT and ICT.
\end{abstract}

Keywords: Energy saving, energy conservation, solar drying, solar thermal, hybrid photovoltaic and thermal collector

\footnotetext{
*Corresponding author: erkata@gmail.com, erkata@pasca.unsada.ac.id
} 


\section{Introduction}

The rapid growth of horizontal and vertical buildings in the greater Jakarta area (Jabodetabek), Indonesia is inseparable from the relatively high population growth, due to the growth of the industrial and service sectors. This is the main factor in the rapid growth of the laundry industry, which is generally a household industry in the densely populated area. Increasing people's motivation and skills towards business [1], such as the laundry industry, contributes to creating new jobs for specific groups and functions as a family economic driver. However, besides causing environmental pollution, the laundry industry also consumes a lot of energy and water. Unfortunately, not many service industries, such as laundry are aware of this environmental issue [2]. If the growth and operation of the laundry industries are not severely controlled, it will cause serious environmental and energy problems shortly. Aside from water and detergent, energy is one of the highest cost components in the laundry process. Therefore, energy savings must be seriously implemented [3,4].

Energy savings in the laundry industry have attracted the attention of researchers in various countries. Rakhmawati et al. [5] advised the medium laundry industries to consider the energy efficiency factor for the selection of washing machines in the industrial era 4.0. Rakhmawati et al. [6] also conducted a key study of the success of a laundry SME in Indonesia in measuring customer satisfaction by designing laundry service quality, which does not yet include energy efficiency. ElNashar et al. [7] analyzed the factors of water consumption in washing machines affecting energy consumption. Budi et al. [8] reported that employee competence with ISO 14000 affected the achievement of targets and environmental performance in a laundry industry. Alborzi et al. [9] analyzed the long washing cycle as having the potential to save energy in the laundry process. Memari et al. [10] used a load sensor and fuzzy logic to calculate cloud-based energy savings by measuring the real-time washing machine's energy consumption parameters.

Based on the results of previous studies, there are many energy-saving opportunities in the laundry industries. However, there are no studies that explain how to control and measure the energy savings in the laundry industry easily and fairly. As an initial step to carry out an energy-saving program in the laundry industry, an energy audit is conducted. Energy audits are the key to developing energy management programs. Energy audits have varying degrees of complexity and can vary greatly from one organization to another. The information obtained is used to identify opportunities to improve efficiency, reduce energy costs, and reduce greenhouse gas emissions. The purpose of this study is to analyze the potential for energy savings and renewable energy applications in a laundry industry by conducting a simple energy audit with the analysis of flow processes from receiving to finishing.

\section{Methodology}

In general, energy audit to an SME scale laundry in the southern part of the Jakarta metropolitan area are mostly observations and data analysis, because there is no direct measurement using the proper tools. Observation data obtained in the field are the result of direct observation or recording on the instrument tools available on the device. Meanwhile, statistical data on production and a year's monthly energy consumption was provided by laundry management. The activity was divided into three stages; 


\subsection{Pre-audit}

At this stage, students who conduct audits are divided into groups with clear details of tasks and responsibilities, starting with conducting energy audits on the floor, analyzing statistical data, and process flow. To be more efficient and focus on the day of the audit, each group must prepare in advance with the audit. Based on the process flow that has been obtained from the beginning, the focus of the audit will be more on the steam system and gas supply, as shown in Figure 1. For this reason, energy audit preparation is focused on items such as; missing pipe insulation, steam trap, condensate return, make-up water, etc.

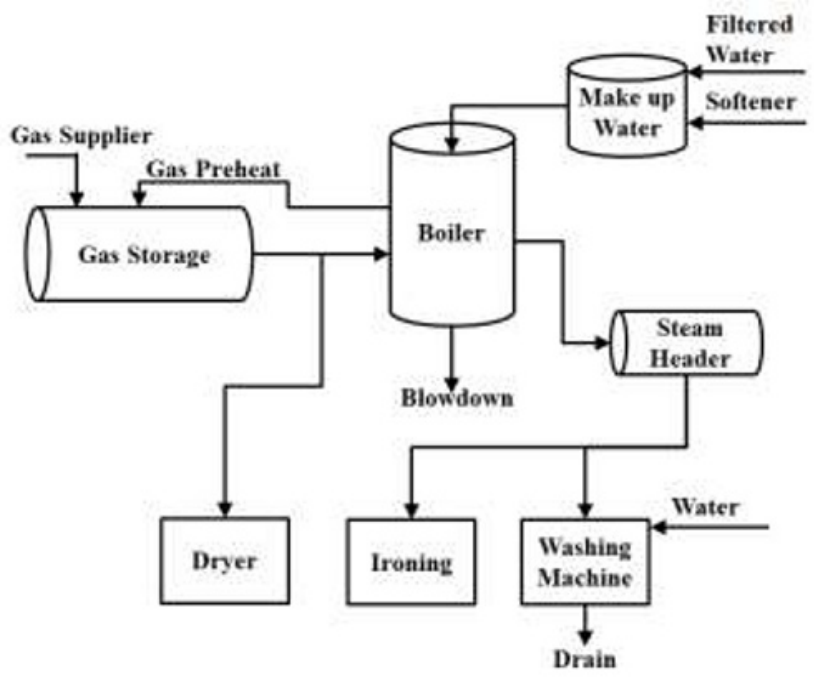

Fig. 1. The steam gas supply system

Figure 2 shows the production process of the small laundry industry. Orders received by the branch office are transported by vehicle to the laundry plant to the process of sorting, washing, rinsing, dry cleaning, ironing, packaging, then sent back to the branch office and picked up by the customer.

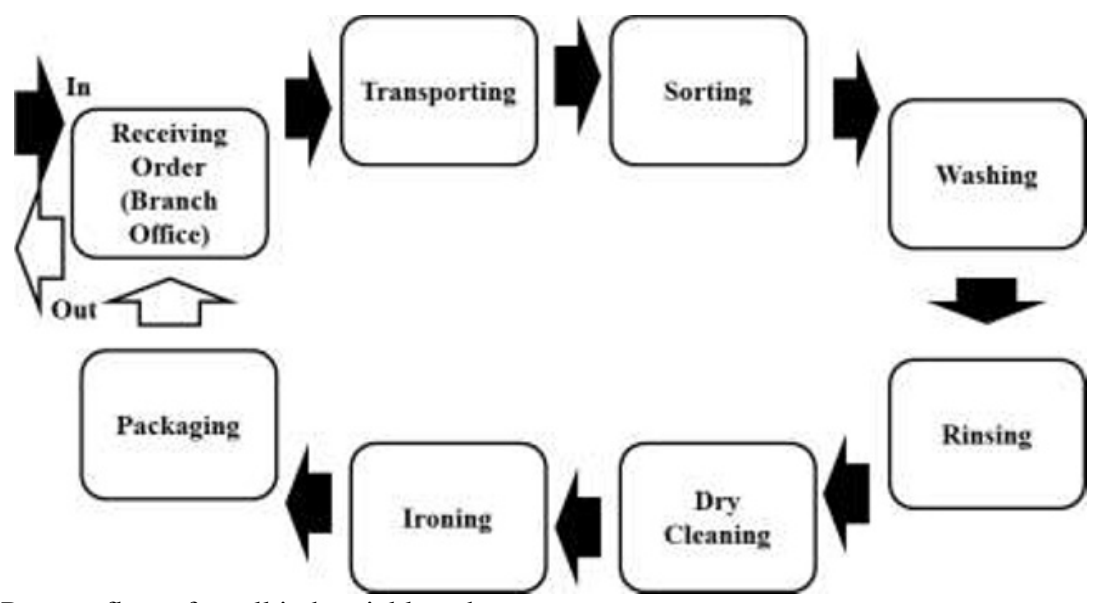

Fig. 2. Process flow of small industrial laundry 
To be fairer in analyzing energy consumption with diverse production volume, it is necessary to convert it into an equivalent production volume, $V_{e}$, expressed by Equation $(1)$;

$$
V_{e}=\frac{S_{1}}{S_{r e f}} V_{1}+\frac{S_{2}}{S_{r e f}} V_{2}+\frac{S_{3}}{S_{r e f}} V_{3}+\frac{S_{n}}{S_{r e f}} V_{n}
$$

Where, $V_{l}, V_{2}, V_{3}, V_{n}$ and $S_{1}, S_{2}, S_{3}, S_{r e f}, S_{n}$ are the types of production volume $1,2,3$, to $n$ and the standard process of production $1,2,3$, reference to $n$, respectively. In this case, $S_{r e f}$ refers to a type of production volume as a reference to production equivalent volume.

\subsection{Site audit}

At this stage, two things must be done. First, conduct an audit on the floor from the beginning (receiving orders) to the end of the process (See Figure 2). Second, collecting and confirming the statistical data for energy and production. At this stage, more activities are carried out with observations on energy waste and production, such as; missing pipe insulation, steam trap, condensate return, blowdown, boiler efficiency, steam pressure, capacity, layout, etc.

\subsection{Post-audit}

At this stage includes completing the audit report that will be submitted or presented to the laundry management, which consists of; audit findings with loss or savings analysis, accompanied by recommendations for further improvement. For improvement, there are three ways to get energy savings, as shown in Figure 3; i). Output remains the same as the input decreases, ii). Output increases with the input stay the same, or, iii). Output increases with the input decreases. In this case, the output is the result of production, while the input is energy, such as gas and electricity.

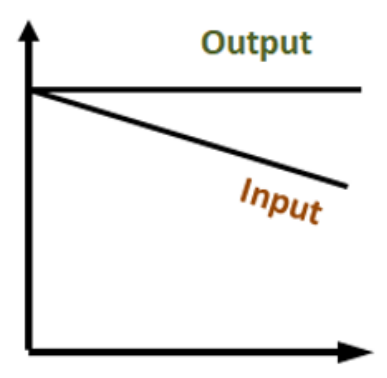

(a)

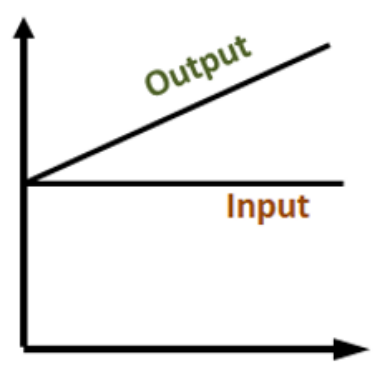

(b)

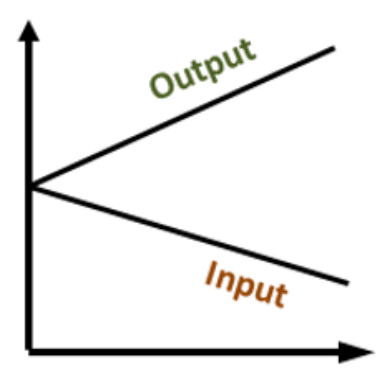

(c)

Fig. 3. Three ways to get savings based on output and input during the process

The energy-saving can be calculated using methods of base measurement of energy savings (BMES), as follows [11] in Equation (2);

$$
E_{S, t o t}=\left(C_{r e t v, b}-C_{r e t v, c}\right) * V_{e, c} * P_{F}
$$

Where, $E_{s, t o t}$ is the total energy cost saved (IDR), $C_{r e t v, b}$ is the previously ratio energy to volume consumed ( $\mathrm{kWh}$ /production volume, or $\mathrm{kg}$ of gas/production volume), $C_{\text {retv, },}$ is the current ratio energy to production volume consumed $(\mathrm{kWh} /$ production volume, or $\mathrm{kg}$ of 
gas/production volume), $V_{\mathrm{e}, \mathrm{c}}$ is the current equivalent volume, and $P_{F}$ is the cost factor (IDR $\mathrm{kWh}^{-1}$, or IDR $\mathrm{kg}^{-1}$ of gas). $C_{\text {retv }, b}$ and $C_{\text {retv }, c}$ formulated as Equation (3);

$$
C_{r e t v, b}=C_{u e, b} / V_{e, b} \quad, \text { or }, \quad C_{r e t v, c}=C_{u e, c} / V_{e, c}
$$

where, $\mathrm{V}_{e, b}$ is the previously base equivalent volume (unit). Both $V_{e, b}$ and $V_{e, c}$ are calculated using Equation (1). Thus, $C_{r e t v, c}, C_{r e t v, c}$, and $V_{e}$ are important elements that must be identified from the initial plan to save energy. The main keys are the $V_{e, b}$ or $V_{e, c} . P_{F}$, the cost factor of energy, must be included the all cost items in electricity or gas billing separately.

\section{Result and discussion}

The main energy sources used are electricity, gas and water. For this reason, audits are focused on devices that use these energy sources. Electrical energy is used as a source of driving energy in laundry machines, while gas is used specifically to produce steam in boilers and hot air in dryers (see Figure 1). The washing and ironing process uses steam including pre-heat for gas storage, while the drying process uses hot air from direct combustion of gas. There is one steam boiler, one steam dryer, 17 irons, and eight gas dryers with a capacity of $5 \mathrm{~kg}$ and $13 \mathrm{~kg}$. The summary of energy wasted based on the findings of the energy audit, as shown in Table 1.

Table 1. Summary findings of energy losses in production

\begin{tabular}{|c|c|c|c|}
\hline No. & Description & Caution & Solution \\
\hline 1. & $\begin{array}{l}\text { Some steam pipe section from the } \\
\text { header to the distribution point in } \\
\text { the condition of missing pipe } \\
\text { insulation. }\end{array}$ & $\begin{array}{l}\text { Not insulated from the } \\
\text { beginning, forgetting to be } \\
\text { reinsulated after a repair, } \\
\text { etc. }\end{array}$ & $\begin{array}{l}\text { The pipe must be } \\
\text { reinsulated soon and } \\
\text { install more steam traps. }\end{array}$ \\
\hline 2. & $\begin{array}{l}\text { Chemical and water consumption } \\
\text { by the boiler is poorly controlled. }\end{array}$ & $\begin{array}{l}\text { Condensate returns are not } \\
\text { utilized. }\end{array}$ & $\begin{array}{l}\text { Install more steam traps } \\
\text { and condensate pipes. }\end{array}$ \\
\hline 3. & $\begin{array}{l}\text { The steam pressure drops from the } \\
\text { boiler to the process. }\end{array}$ & $\begin{array}{l}\text { The steam-pipe installation } \\
\text { turns from the boiler to } \\
\text { process. }\end{array}$ & $\begin{array}{l}\text { Rearranges production } \\
\text { layouts efficiently. }\end{array}$ \\
\hline 4. & $\begin{array}{l}\text { The water content is still high in } \\
\text { the final washing process. }\end{array}$ & Poor drying process & $\begin{array}{l}\text { Setting proper drying } \\
\text { time vs type of material. }\end{array}$ \\
\hline 5. & $\begin{array}{l}\text { The washing machine capacity is } \\
\text { not used optimally. }\end{array}$ & $\begin{array}{l}\text { The washing process is } \\
\text { based on a batch order. }\end{array}$ & $\begin{array}{lr}\text { The batch } & \text { must be } \\
\text { arranged } & \text { from } \\
\text { receiving. } & \end{array}$ \\
\hline 6. & $\begin{array}{l}\text { Energy consumption is not } \\
\text { controlled properly, also without } \\
\text { the target of energy consumption. }\end{array}$ & $\begin{array}{l}\text { There is no energy } \\
\text { performance ratio, or base } \\
\text { measurement } \\
\text { savings (BMES). }\end{array}$ & $\begin{array}{l}\text { Completing } \quad \text { and } \\
\text { periodically controlling } \\
\text { BMES. }\end{array}$ \\
\hline 7. & $\begin{array}{l}\text { There is no energy awareness or } \\
\text { energy campaign. }\end{array}$ & $\begin{array}{l}\text { There is no energy } \\
\text { management control system } \\
\text { (EMCS). }\end{array}$ & $\begin{array}{l}\text { Set up energy goal and } \\
\text { system through EMCS. }\end{array}$ \\
\hline
\end{tabular}

Figure 4 illustrates some examples of heat energy wasted, notably missing pipe insulation that occurs in the header section of the boiler (i), steam gauge for preheating the gas before burning (ii), distribution point in the ironing process (iii), and discharge of condensate air without returned to the boiler (iv). Based on observations, missing pipe insulation has been caused by repairs around the area and resulted in damaged insulation, without any replacement. Steam traps are only found at a few points, especially in the area around the boiler. 


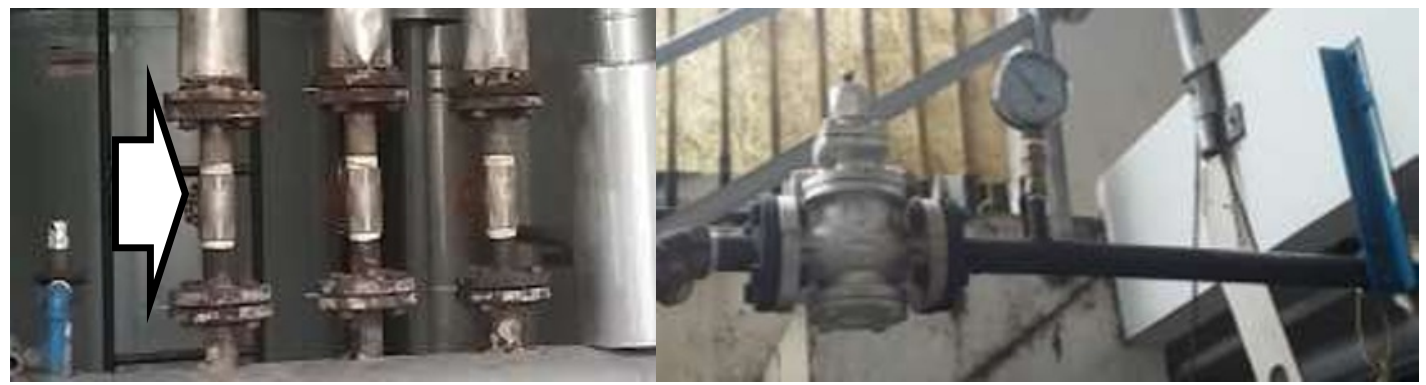

(a)

(b)

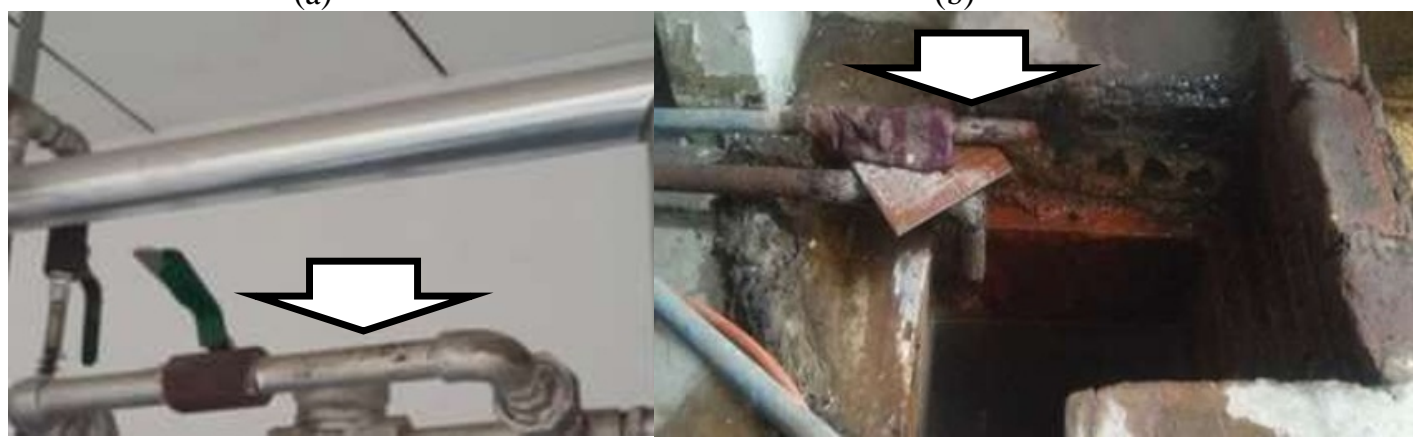

(c)

(d)

Fig. 4. Some findings of energy losses in missing pipe insulation and condensate return

Figure 5 illustrates a graph of monthly production (kg of production) with electricity consumption $(\mathrm{kWh})$. As seen in Figure 5(a), the trend in the ratio of electricity consumption/production ( $\mathrm{kWh} \mathrm{kg}^{-1}$ of production) seems to decrease. However, the correlation between production and electricity consumption is very small, as shown in $\mathrm{R}^{2} \approx 0.03$ in Figure 5(b).

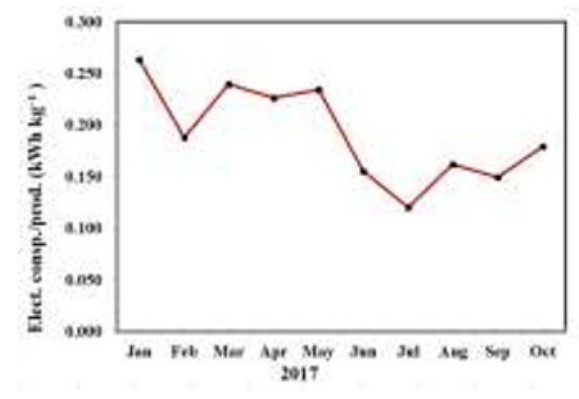

(a)

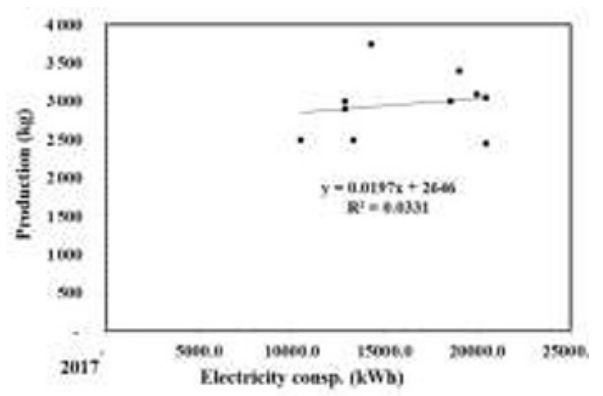

(b)

Fig. 5. Production vs Electricity consumption, a). Monthly kWh per production, b). Scatter diagram

Figure 6 illustrates a graph of monthly production ( $\mathrm{kg}$ of production) with gas consumption ( $\mathrm{kg}$ of gas). As seen in Figure 6(a), the trend in the ratio of electricity consumption/production ( $\mathrm{kg}$ of gas $\mathrm{kg}^{-1}$ of production) seems to decrease. However, the correlation between production and electricity consumption is very small, as shown in $\mathrm{R}^{2} \approx 0.003$ in Figure 6(b). 


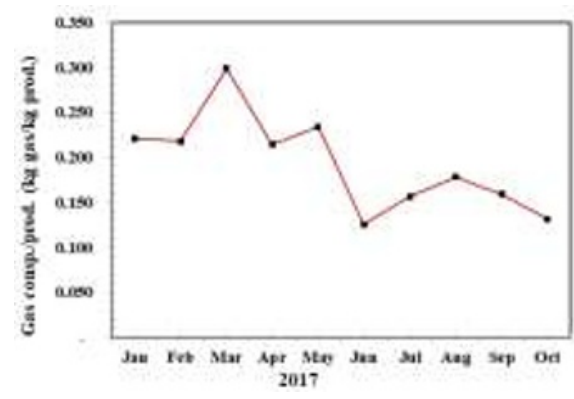

(a)

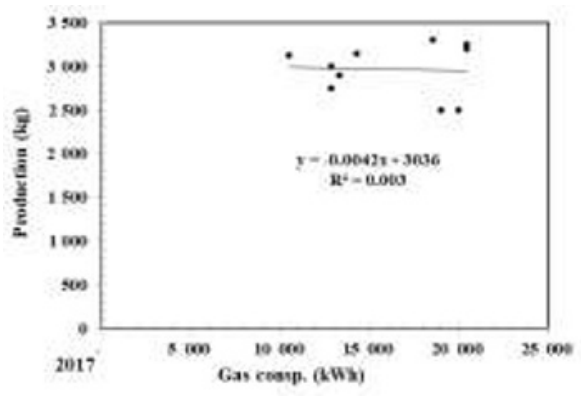

(b)

Fig. 6. Production vs Gas consumption, a). Monthly trend, b). Scatter diagram

Based on the analysis of wasted energy and production trends on energy consumption, at least three causes can be discussed. First, there is no equivalent production volume, even though the fabric being processed has different characteristics with different processes. Besides, the production process is based on a batch of each order, meaning that each customer order is processed separately without being mixed. This is why the washing machine is under capacity. This is why direct total production cannot be used to measure the energy consumed by the production for the diverse products and processes. From a study [12], energy savings can also be done by classifying laundry fabrics on vertical axis washing machines. For this reason, equivalent production must be used to represent these variations, as explained in Equation (1).

Second, energy consumption is measured in total. This is caused by energy meter reading not being done regular basis such as daily or weekly, so there is no alarm control in achieving the ratio of energy consumption to production. The reason, laundry management does not understand how important it is to control energy performance regularly, as important as the energy management control system for continuous improvement in energysavings [11].

Third, there are no indicators to measure how efficient energy consumption is. This is the effect of the first and second, so there is no ratio of energy consumption to production as a reference, or base of energy, as explained in Figure 2 and Equation (2). By analyzing process flow, increasing production and energy efficiency as suggested in Figure 2(c), it can be done by shortening the process, method change, etc. This can be done with process engineering, combining engine design with the application of certain chemicals. To get excellent and efficient laundry machine performance with low initial investment costs but provides preventive maintenance guarantees, laundry machine leasing models should be considered especially for the new laundry companies [13]. To reduce the dependency of laundry industries on fossil energy, the application of renewable energy for both drying and washing processes can be synchronized with the development of Smart Cities supported by Smart Grid [14, 15], especially with the hybrid photovoltaic and thermal (PVT) collector application $[16,17]$.

The results of the study can provide an overview and understanding to carry out energysaving programs, particular in laundry companies, or generally in other industries. For an environmentally friendly laundry industry, laundry wastewater needs to be treated properly to reduce chemical oxygen demand (COD) [18] and phosphate [19]. Also, the energyefficient laundry should be one of the items in laundry service quality as a determinant in customer satisfaction [6]. For future research and development direction, laundry machines must be smart and efficient towards Industry 4.0 [5], implementing the information and communication technology (ICT) [20], integrating fuzzy logic measurement with cloud computing [10], and also the use of renewable energy technology as a driving force and for 
the needs of the production process by laundry machines, which require electricity and heat energy [14-17].

\section{Conclusion}

Based on a simple audit that has been carried out to an SME laundry industry in the southern part of Jakarta metropolitan area (Jabodetabek), provides an overview of potential energy savings that can be done quickly and easily by laundry management. For this reason, laundry management must act immediately by covering up energy leakage or wasted energy, which has been identified during the energy audit. Furthermore, the ratio of energy consumption to production must be controlled regularly by developing an energy management control system. Besides, the use of renewable energy that produces electricity as a driving energy or heat energy for the production process, using a solar dryer or a hybrid photovoltaic and thermal (PVT) collector. Further research and development of the laundry industry must be more environmentally sound, adjusting to the needs of IoT and ICT-based industrial revolution 4.0.

Thanks to the Laundry management for providing an energy audit opportunity with data support, and also to the students of the graduate school of the renewable energy program, Darma Persada University for conducting the energy audit: Rudy Heryadi, Aprillia Ika Warsanti, Frans Binto Mangatur, Siswo Adibowo, Nugroho Priyo Utomo, Rudolf, Deodata Leela Andiavitri, Jumino, Tanda Akhesta Sunu Wuriyanto, Agung Setiabudi, Brenda Elisabeth Margaret Macawalang, Wiwi Wijayanti, Khairul, and Luthfi Jauhari.

\section{References}

1. N.D. Sunengsih, A. Winata, W. Widiastuti, J. Phys. Conf. Ser., 1469,1:1-4(2020). https://iopscience.iop.org/article/10.1088/1742-6596/1469/1/012063/meta

2. H.D. Oliveira, J. Louse, S. Alves, J. Clean. Prod., 246:1-22(2020). https://www.sciencedirect.com/science/article/pii/S0959652619338557

3. K. Ellmer, M. Fuchs, U. Bauer, T. Schneider, P.U. Thamsen, T. Morgenthal, et al., "J. Clean. Prod., 153:539-547(2017). https://www.sciencedirect.com/science/article/pii/S0959652615010884

4. E. Kosasih, A. Yuniawati, V. Suryaputra, "Model for Calculating Cost of Laundry Services by Considering Environmental Impacts and Costs," vol. 20, no. 2, 2019. https://pdfs.semanticscholar.org/1a7b/3c5a14570696e16ec4110ec037f2e07a2055.pdf

5. T. Rakhmawati, S. Sumaedi, N.J. Astrini, I.G.M.Y. Bakti, M. Yarmen, S. Damayanti, IOP Conf. Ser. Mater. Sci. Eng., 722,1:1-11(2020). https://iopscience.iop.org/article/10.1088/1757-899X/722/1/012048/meta

6. T. Rakhmawati, S. Sumaedi, I.G.M.Y. Bakti, Designing customer satisfaction measurement system for a sme laundry services company, Proceedings of the International Conference on Industrial Engineering and Operations Management (Bandung, Indonesia, 2018), 2018,1:1660-1670(2018). http://ieomsociety.org/ieom2018/papers/474.pdf

7. Z. ElNashar, O. Cherkaoui, Z. Zlatev, E. ElNashar, Appl. Res. Tech. Technol. Educ., 16,2:121-130(2018).

https://www.researchgate.net/profile/Elsayed_Elnashar/publication/326160969_LAU NDRY WASHING_MACHINE_FOR_CONSUMPTION_OF_CLOTHING_WATE R_AND_ENERGY_IN_EGYPT/ 
8. I.Y. Budi, M. Karuniasa, R. Nurcahyo, IOP Conf. Ser. Earth Environ. Sci., (Malang, Indonesia, 2019), 456,1:1-4(2020). https://iopscience.iop.org/article/10.1088/17551315/456/1/012021/meta

9. F. Alborzi, A. Schmitz, R. Stamminger, Energy Effic., 10:823-838(2017) https://link.springer.com/article/10.1007/s12053-016-9486-Z

10. P. Memari, S.S. Mohammadi, S.F. Ghaderi, Fed. Conf. Comput. Sci. Inf. Syst., 15:697-700(2018). https://ieeexplore.iee.org/abstract/document/8511234/

11. E. Yandri, R. Ariati, A.S. Uyun, R.H. Setyobudi, O. Anne, H. Susanto, et al., , IOP Conf. Ser. Earth Environ. Sci. Pap., (2019), 490:012005(2020). https://iopscience.iop.org/article/10.1088/1755-1315/490/1/012005/meta

12. M. Maggipinto, E. Pesavento, F. Altinier, G. Zambonin, A. Beghi, G.A. Susto, Energies, 12,21:1-13(2019). https://www.mdpi.com/1996-1073/12/21/4080

13. A. Supriatna, M.L. Singgih, E. Widodo, N. Kurniati, AIP Conference Proceedings, 2114:060011(2019). https://aip.scitation.org/doi/abs/10.1063/1.5112482

14. E. Yandri, R.H. Setyobudi, H. Susanto, K. Abdullah, Y.A. Nugroho, S.K. Wahono, et al., E3S Web of Conferences, 188:00007(2020) https://doi.org/10.1051/e3sconf/202018800007

15. B. Novianto, K. Abdullah, A.S. Uyun, E. Yandri, S.M. Nur, H. Susanto, et al. E3S Web of Conferences, 188:00005(2020) https://doi.org/10.1051/e3sconf/202018800005

16. E. Yandri, Renew. Energy, 111:344-352(2017). https://www.sciencedirect.com/science/article/pii/S0960148117302860

17. E. Yandri, Sol. Energy Mater. Sol. Cells, 201:110066(2019). https://www.sciencedirect.com/science/article/pii/S0927024819303952

18. N. Herlina, M. Turmuzi Lubis, A. Husin, I. Putri, MATEC Web Conf., 276:06015 (2019).

https://www.matec-

conferences.org/articles/matecconf/abs/2019/25/matecconf_icancee2019_06015/mate cconf_icancee2019_06015.html

19. M.S. Sinaga, S.W. Astuti, E. Gultom, IOP Conf. Ser.: Mater. Sci. Eng. 801:012067 (2020).

https://iopscience.iop.org/article/10.1088/1757-899X/801/1/012067/meta

20. N. Syamsiyah, E. Novianti, E.A. Susilawati, E.Y. Astuty, M.F. Sesunan, J. Phys. Conf. Ser., 1469,1(2020).

https://iopscience.iop.org/article/10.1088/1742-6596/1469/1/012093/meta 